\title{
IJTIHAD SAHABAT DI TENGAH PERGUMULAN TRANSFORMASI PEMIKIRAN HUKUM
}

\author{
Oleh: Tri Ermayani \\ (MKU-UNY)
}

\begin{abstract}
Abstrak
Ijtihad merupakan dasar hukum yang ketiga sesudah al-Qur'an dan as-Sunnah. Meski demikian kadang ada yang mempertanyakan atau bahkan mempertentangkan tentang nilai akurat dan validitasnya. Terlepas dari berbagai tanggapan atau argumen masing-masing para tokoh hukum Islam, ada baiknya kita menengok setting kehidupan para sahabat ketika mereka melakukan sesuatu hal yang berkaitan dengan legalitas ijtihad di tengah kebutuhan akan kepastian hukum atas sesuatu perkara yang muncul di setiap waktu dalam kehidupan yang sarat akan perkembangan dan perubahan.

Sepeninggal Rasulullah berbagai perkembangan dan perubahan dalam kehidupan ini semakin mengisyaratkan perlunya ijtihad. Berbagai persoalan yang sangat kompleks bermunculan, sehingga memerlukan kepastian hukum, karena akan diterapkan untuk kehidupan ummat Islam yang sesuai dengan Syariat Islam. Oleh karena itu, perlu juga ummat Islam memahami hukum dari aspek historis. Ijtihad di zaman sahabat telah dicontohkan oleh para sahabat, seperti: Abu Bakar ash-Shiddiq, Umar bin Khaththab, dan Ali bin Abi Thalib.

Masing-masing sahabat pun memiliki kecenderungan maupun orientasi yang khas tentang pemikirannya. Hal tersebut dipengaruhi oleh sikap mental dan ketajaman pola pikir mereka. Namun demikian perbedaan tersebut tidaklah menjadi pertentangan, sebaliknya semua perbedaan itu justru dijadikan sebagai landasan untuk bersikap lebih arif. Rasulullah sesungguhnya telah mengisyaratkan tentang perbedaan di kalangan ummat Islam justru akan membawa rahmat.
\end{abstract}

\section{Pendahuluan}

Masyarakat senantiasa mengalami perubahan. Perubahan masyarakat itu dapat berupa perubahan tatanan sosial, budaya, sosial ekonomi dan lain sebagainya. Menurut para ahli linguistik serta semantik, bahasa akan mengalami perubahan setiap sembilan puluh tahun. Hal itu mengandung arti bahwa ada perubahan yang terjadi 
dalam masyarakat. Dan juga senada dengan apa yang pernah dikatakan oleh Nabi Muhammad SAW., bahwa setiap seratus tahun (seabad) akan ada orang yang bertugas memperbaharui pemahaman keagamaan (Fathurrahman Djamil, 1999: 163).

Hukum Islam, betapapun, telah berkembang dengan masalahmasalah baru yang mendesak dari waktu ke waktu sejak masa Nabi SAW., dan diciptakan dan diciptakan kembali (created and recreated), diinterpretasikan dan juga di-reinterpretasikan, sesuai dengan berbagai varian wilayah persoalan yang dibahas. Proses dari memikirkan kembali dan mereinterpretasikan hukum secara bebas adalah diketahui dengan ijtihad. Di awal periode, ra'y (considered personal opinion) merupakan instrumen dasar daripada ijtihad (Ahmed Hasan, 1999: 163).

Sejarah telah mencatat, bahwa ijtihad telah dilaksanakan dari masa ke masa. Pada masa awal Islam, ijtihad telah dilaksanakan dengan baik dan kreatif. Pada masa berikutnya muncul sederetan mujtahid kenamaan. Keadaan ini berlangsung sampai masa keemasan umat Islam. Pada masa inilah dihasilkan pemikiran dan karya yang cukup berharga bagi umat Islam berikutnya. Akan tetapi yang akan dibahas oleh penulis di sini adalah pelaksanaan ijtihad sebagai transformasi pemikiran hukum Islam di masa shahabat Rasul (masa klasik) sebagai wacana perubahan terhadap pemikiran hukum oleh shahabat dikaitkan dengan realitas masyarakat Islam pada waktu itu.

Sebelum kita memasuki pembahasan ijtihad secara luas, maka kita perlu lebih dahulu menyimak awal mula ijtihad itu sebagai metode penemuan hukum, yaitu berangkat dari kondisi ketika Nabi SAW akan mengutus Mu'adz ibn Jabal ke Yaman untuk bertindak sebagai hakim, beliau bertanya kepada Mu'adz: "Apa yang akan kau lakukan jika kepadamu diajukan suatu perkara yang harus diputuskan?" Mu'adz menjawab: “Aku akan memutuskannya berdasarkan ketentuan yang termaktub di dalam Kitab Allah (alQur'an)!" Nabi bertanya lagi: "Bagaimana jika di dalam Kitab Allah tidak terdapat ketentuan tersebut?" Mu'adz menjawab: "Dengan berdasarkan Sunnah Rasulullah SAW." Nabi bertanya lagi: "Bagaimana jika ketentuan tersebut tidak terdapat pula di dalam Sunnah Rasulullah?” Mu'adz menjawab: “Aku akan berijtihad dengan pikiranku, aku tidak akan membiarkan satu perkara pun tanpa putusan." Lalu Mu'adz mengatakan: "Rasulullah kemudian menepuk dadaku seraya mengatakan: 'Segala puji bagi Allah yang telah memberikan taufik kepada utusanku untuk hal yang melegakanku'." 
Menyimak hadits riwayat Mu'adz tersebut di atas, maka dapat diperoleh kesimpulan bahwa sumber-sumber asli hukum Islam adalah al-Qur'an dan Sunnah. Apabila di dalam al-Qur'an maupun Sunnah tidak terdapat ketentuan hukum sesuatu yang harus diputuskan untuk menyelesaikan suatu perkara, maka diupayakan menemukan hukumnya melalui ijtihad. Sehingga ijtihad di sini merupakan penggunaan pikiran semaksimal mungkin untuk memperoleh ketentuan hukum syara'.

Secara umum harus ada pemahaman bahwa orang yang melakukan ijtihad harus benar-benar Muslim: kukuh akidahnya, baik ibadahnya, dan mulia akhlaknya, dan harus memenuhi syarat-syarat berpikir yang benar. Selain itu juga mengetahui bahasa yang dipergunakan di dalam dalil-dalil yang dipergunakan, terutama bahasa al-Qur'an dan Sunnah harus benar-benar diketahui (sejauh memungkinkan beristinbath atau memetik kesimpulan hukum) dari alQur'an dan Sunnah. Dan juga harus mengetahui secara baik seluk beluk al-Qur'an dan Sunnah. Mengetahui dengan benar ayat-ayat alQur'an dan hadits-hadits yang menyangkut masalah yang dibahas. Jiwa syariat dan tujuannya untuk mewujudkan kebaikan hidup manusia pun harus benar-benar diketahui.

Dengan memahami pengertian dan macam-macam ijtihad, maka kita dapat membuka wacana tentang transformasi pemikiran dan ijtihad, karena kedua istilah tersebut merupakan dua hal penting yang tidak dapat dipisahkan satu dengan lainnya, terlebih lagi apabila dilihat dari wilayah kekinian. Kedua istilah tersebut sering diidentikkan pada penafsiran maknanya, karena antara keduanya memiliki tujuan yang sifatnya hampir sama, terutama bila dihubungkan dengan usaha aktualisasi ajaran Islam, yang bertujuan untuk melahirkan pemikiran baru. Apabila ditelusuri lebih jauh, di antara keduanya terdapat perbedaan, terutama jika dilihat dari segi objeknya.

\section{Pengertian dan Macam-Macam Ijtihad}

Secara etimologis, ijtihad berakar pada kata jahada yang berarti "kesulitan atau kesusahan". Menurut ilmu sharaf, kata ijtihad bentuknya mengikuti timbangan (se-wazn) yajtahidu yang menunjukkan arti berlebih (mubalaghah) dalam melaksanakan suatu perbuatan (Umar Syihab, 1996: 47). Sehingga berijtihad di sini bukanlah kegiatan yang mudah atau ringan, tetapi mengandung kesulitan serta membutuhkan pengarahan tenaga serta daya pikir yang 
maksimal. Sedangkan secara terminologis, ijtihad menurut 'Abd alWahab Khallaf (1994: 338) adalah sebagai pengerahan daya upaya untuk sampai kepada hukum syara' dari dalil yang terinci, dengan bersumber dari dalil-dalil syara'. Kemudian menurut Muhammad Abu Zahrah (1994: 567) ijtihad adalah upaya mengerahkan seluruh kemampuan dan potensi untuk sampai pada suatu perkara atau perbuatan. Ijtihad menurut ulama Ushul ialah usaha seorang yang ahli fiqh yang menggunakan seluruh kemampuannya untuk menggali hukum yang bersifat amaliah (praktis) dari dalil-dalil yang terperinci.

Dari ketiga definisi tersebut terbatas pada ruang lingkup ijtihad kepada persoalan hukum saja. Seseorang yang melakukan pengkajian di luar bidang hukum Islam tidak disebut sebagai mujtahid. Atau dengan kata lain, pengertian tersebut terlalu jauh dari makna ijtihad yang sebenarnya, karena pengkajian yang dilakukan oleh para mujtahid dalam disiplin ilmu lain. Mereka membutuhkan pula pengerahan daya upaya atau daya pikir untuk mendapatkan hasil kajian yang bersifat mapan dan benar, sebagaimana yang dibutuhkan oleh ulama-ulama yang bergerak dalam disiplin ilmu hukum Islam. Oleh sebab itu, sebaiknya pengertian ijtihad itu dikembalikan kepada pengertian etimologisnya, yaitu menyangkut semua daya upaya yang mengarah kepada pengkajian, baik itu kaitannya pada ilmu hukum ataupun ilmu-ilmu yang lainnya (ilmu kalam atau ilmu tasawuf), yang semuanya itu dikelompokkan sebagai ijtihad, sehingga orang yang bergelut di dalamnya disebut mujtahid.

Untuk lebih memahami makna ijtihad, penulis menukil juga pendapat dari Yusuf Qardhawi dkk. (1987: 74) yang mengartikan ijtihad sebagai usaha maksimal dalam melahirkan hukum-hukum syariat dari dasar-dasarnya melalui pemikiran dan penelitian serius. Status hukumnya fardhu kifayah. Ijtihad juga bisa diberikan status hukum fardhu 'ain atas pribadi yang memiliki kemampuan untuk itu, sementara ia sendiri menganggap tidak ada seorang pun dapat menggantikan kedudukannya. Sehingga ijtihad dapat dipahami sebagai optimalisasi kinerja seorang faqih (mujtahid) untuk menemukan solusi atas persoalan hidup masyarakat yang memerlukan kepastian hukum syariat dengan segenap pemikiran dan penelitian yang serius, dengan mengacu pada pedoman hukum syariat.

Dalam pemakaian umum, kata Arab ijtihad berarti upaya yang sungguh-sungguh, baik fisik maupun mental dalam aktivitas tertentu. Dalam pengertian teknis hukum, ijtihad menunjukkan penggunaan kemampuan mental seorang faqih secara seksama untuk menemukan pemecahan bagi suatu kasus hukum (Wael B. Hallaq, 2001: 264). 
Selanjutnya mengenai pembagian ijtihad, pada prinsipnya ijtihad dapat dibagi ke dalam dua bagian, yaitu ijtihad kolektif (jama'i) dan ijtihad perseorangan (fardi). Pembagian ini berdasarkan pada praktik ijtihad sejak masa Nabi Muhammad SAW. Ijtihad perseorangan ialah ijtihad yang dilakukan secara mandiri oleh seseorang yang mempunyai keahlian dan hasil ijtihadnya belum mendapat persetujuan dari ulama atau mujtahid lain. Ijtihad perseorangan ini diakui dalam Islam dan merupakan hak bagi setiap muslim yang memiliki keahlian dalam menganalisis dan mengkaji suatu masalah secara mendalam. Ijtihad semacam ini tidak merupakan kewajiban bagi orang lain untuk mengikutinya, pengamalan hasil ijtihad fardi hanya menjadi kewajiban bagi orang yang menghasilkannya.

Jika pengertian ijtihad dibandingkan dengan pengertian transformasi pemikiran seperti yang dikemukakan terdahulu, dapat dipahami lebih lanjut bahwa ijtihad merupakan bagian dari transformasi pemikiran. Seorang mujtahid tidak mutlak menjadi seorang tokoh transformasi, akan tetapi seorang tokoh transformasi tergolong mujtahid. Oleh sebab itu, ijtihad memiliki kedudukan yang sangat penting dalam upaya transformasi pemikiran. Untuk itulah kita tentunya harus menengok kembali tentang ijtihad terlebih ijtihad di era klasik yang sudah jelas sebagai wacana perkembangan pemikiran hukum Islam di saat-saat awal tokoh Islam, yang dalam hal ini sahabat Nabi harus berjuang keras meyelesaikan masalah-masalah yang muncul pada waktu itu sebagai titik tolak dari perkembangan pemikiran hukum Islam pada periode-periode berikutnya yang lebih kompleks.

Secara makro, ijtihad merupakan sub dari transformasi pemikiran. Keduanya mempunyai arah dan tujuan yang sama, yakni bertujuan mengantisipasi segala persoalan sosial kemasyarakatan yang muncul dalam dunia Islam, sehingga eksistensi universitalitas, kedinamisan serta keluwesan hukum Islam tetap dapat dipertahankan.

Praktik ijtihad pada masa Nabi Muhammad SAW. dan sahabat yang merupakan contoh dari ijtihad jama'i ini ialah Nabi Muhammad SAW. menerima dan membenarkan jawaban Mu'adz bin Jabal ketika ditanya oleh beliau: "Apa yang kamu lakukan dalam memutuskan perkara bila tidak ada nas al-Qur'an dan hadits Nabi SAW". Mu'adz menjawab: ajtahidu bi ra'yi. Dan juga tentang instruksi 'Umar bin Khaththab r.a. kepada Abu Musa al- Asy'ari untuk berijtihad dengan menggunakan qiyas. Beliau berkata: "Gunakanlah pemahaman secara mendalam menyangkut masalah yang tidak terdapat nasnya dalam alQur'an dan hadits Nabi SAW. Cari dan upayakanlah mengenal 
kemiripan dan keserupaannya, lalu analogikan (qiyaskan) semua perkara yang semacam itu.

Sedangkan kategori ijtihad kolektif (jama'i) ialah ijtihad yang dilakukan secara bersama atau bermusyawarah terhadap suatu masalah, dan pengamalan hasilnya menjadi tanggung jawab bersama; atau ijtihad yang dilakukan oleh seorang mujtahid dan hasilnya mendapatkan persetujuan ulama lain. Sehingga ijma' sebagai sumber hukum yang ketiga merupakan hasil ijtihad kolektif.

Ijtihad kolektif merupakan cara yang sering dilakukan oleh sahabat, ketika akan memutuskan hukum suatu perkara yang belum ada penetapannya (nas al-Qur'an dan hadits Nabi SAW.), termasuk ketika Nabi Muhammad SAW. masih hidup. Ijtihad kolektif dapat dibagi dua: 1) musyawarah secara langsung sejumlah mujtahid, yang hanya terjadi secara murni pada masa sahabat, khususnya pada pemerintahan 'Umar bin Khattab r.a., karena di samping perbedaan pendapat masih sempit, juga wilayah kekuasaan Islam belum luas, dan 2) ijtihad kolektif dalam bentuk ijma' teoritis, sebagaimana yang dilakukan oleh ulama ushul.

\section{Ijtihad Sahabat}

Ada tiga hal pokok yang berkembang pada waktu itu sehubungan dengan hukum Islam. Pertama, begitu banyaknya muncul kejadian baru yang membutuhkan jawaban hukum secara lahiriah tidak dapat ditemukan jawabannya dalam al-Qur'an maupun penjelasan dari Sunnah Nabi. Kedua, timbulnya masalah-masalah yang secara lahir telah diatur ketentuan hukumnya dalam al-Qur'an maupun Sunnah Nabi, namun ketentuan itu dalam keadaan tertentu sulit untuk diterapkan dan menghendaki pemahaman baru agar relevan dengan persoalan yang tengah dihadapi. Ketiga, yakni dalam alQur'an ditemukan penjelasan terhadap suatu kejadian secara jelas dan terpisah. Bila hal itu berlaku di dalam kejadian tertentu, maka para sahabat menemui kesulitan dalam menerapkan dalil-dalil yang ada (Amir Syarifuddin, 1997: 22).

Berangkat dari kondisi tersebut maka lahirlah ijtihad yang berperan dalam dua lapangan. Pertama di bidang di mana nash-nash (teks) yang tegas tidak menyebutkannya. Dengan demikian mujtahid dapat leluasa memberikan interpretasinya dan merealisasikannya sesuai dengan kehendak agama melalui proses ijtihad, analogi, mashlahah mursalah (kemaslahatan terlepas), istihsan, istishhab (pemberlakuan hukum yang sudah ada), dan sebagainya. 
Bidang garapan yang kedua ialah teks-teks zhanni (relatif benar, dalil yang mendatangkan dugaan kuat), baik zhanni dalam hal otentisitasnya (hadits-hadits Nabi pada umumnya berstatus demikian) maupun zhanni dalam hal pengertian yang dapat dipahami. Teks-teks hukum seperti ini merupakan bidang garapan mujtahid. Adapun bidang yang tertutup bagi kemungkinan ijtihad ialah wilayah alqath'iyat (kepastian-kepastian), misalnya tentang dasar dan pokok agama.

Secara kongkrit dalam memaparkan ijtihad sahabat-sahabat Nabi Muhamad SAW., terutama sepeninggal beliau, maka perlu sekali untuk memahami batasan daripada sahabat yang dimaksud serta bagaimana status mereka menurut pandangan para ulama. Sebab dalam hal ini selain Nabi Muhammad SAW., para sahabatlah yang dipandang sebagai figur utama dalam tata cara berijtihad, baik ketika mereka masih bersama beliau maupun setelah beliau tidak lagi bersama mereka.

Dalam lintasan sejarah, ijtihad telah ada sejak zaman Rasulullah SAW. Hal ini dapat dilacak antara lain dari riwayat berikut: Dari Amr ibn al-"Ash r.a. ia mendengar Rasulullah SAW. bersabda, "Apabila seorang hakim hendak menetapkan hukum kemudian dia berijtihad dan ternyata benar ijtihadnya, maka baginya dua pahala, dan apabila dia hendak menetapkan hukum kemudian dia berijtihad dan ijtihadnya ternyata salah, maka untuknya satu pahala" (Amir Mu'allim Yusdani, 1997: 25). Rasulullah memang telah mempersiapkan jalan berijtihad bagi mereka dengan melatih dan merelakan mereka untuk berijtihad, baik ijtihadnya salah atau benar. Riwayat yang dikeluarkan al-Baghawi dari Maimun bin Mahran berikut ini menggambarkan dengan jelas bagaimana mereka melakukan istinbath. Dia berkata: "Sesungguhnya Abu Bakar, kalau ada pertikaian yang disampaikan kepadanya, ia akan melihat ke Kitabullah. Kalau ditemukan penyelesaiannya dalam Kitabullah, ia akan memutuskannya dengan Kitabullah. Kalau tidak terdapat pada Kitabullah dan ia menemukannya dalam al-Sunnah, ia akan berhukum dengan alSunnah. Kalau sulit menemukannya, ia akan keluar dan bertanya kepada orang lain, "Telah sampai kepadaku kasus begini dan begini, apakah anda mengetahui Rasulullah pernah memutuskan masalah itu?' Terkadang kelompok (yang ditanyakan) secara keseluruhan sepakat menyebutkan ada keputusan tentang masalah itu dari Rasul SAW. Kalau pada kelompok itu sulit ditemukan sunnah, dia mengumpulkan para pemimpin dan orang terkemuka untuk bermusyawarah. Kalau pendapat mereka disepakati bersama, maka dia akan memutuskan 
hukum dengan pendapat itu." (Syekh Muhammad Ali as-Saayis, 1995: 34).

Umar r.a. juga pernah melakukan tindakan seperti itu. Jika ia kesulitan menemukan dalam al-Qur'an dan Sunnah, ia akan mencari apakah Abu Bakar pernah memutuskan masalah itu. Kalau ia temukan, ia memutuskan hukum dengan keputusan Abu Bakar. Jika tidak juga ditemukan, maka ia mengundang para pemimpin. Dan jika mereka sepakat, Umar memutuskan masalah itu dengan berdasarkan hasil kesepakatan.

Pada masa sahabat, wilayah kekuasaan Islam semakin meluas keluar melintasi wilayah Jazirah Arab sendiri. Oleh karenanya banyak penduduk non-Arab yang memeluk agama Islam, sehingga hal ini merupakan suatu tantangan tersendiri bagi dunia Islam di waktu itu yang juga ditandai dengan munculnya berbagai peristiwa atau permasalahan yang sebelumnya tidak atau belum pernah terjadi. Kemudian masalah inilah yang menjadi tanggung jawab para sahabat untuk dihadapi serta dipecahkan sesuai dengan prinsip syariat Islam, karena wahyu dan sunnah Rasul tidak ada lagi, sementara persoalan yang mereka hadapi semakin berkembang. Para tokoh mujtahid yang termasyhur di zaman sahabat di anataranya 'Umar ibn al-Khaththab, 'Ali ibn Abi Thalib, dan 'Abdullah ibn Mas'ud (Nasrun Haroen, 1997: 8).

Untuk pertama kalinya ijtihad dilakukan terhadap masalah yang pertama timbul dalam Islam, yaitu tentang siapa pengganti Nabi Muhammad sebagai khalifah atau kepala negara setelah beliau wafat? (Harun Nasution, 1996: 109). Menurut ijtihad sahabat dalam bentuk musyawarah, ditetapkan bahwa Abu Bakar r.a. adalah sebagai khalifah pertama setelah melalui diskusi yang serius.

Masalah kedua ialah menghadapi para pembangkang zakat dan orang-orang murtad setelah Nabi Muhammad SAW. wafat. Dalam persoalan memerangi orang murtad tidak terjadi perselisihan dari para sahabat. Namun masalah pembangkang zakat, terjadi perbedaan pendapat di kalangan mereka. Menurut ijtihad 'Umar r.a. para pembangkang zakat itu tidak perlu diperangi dengan alasan bahwa disebutkan dalam sebuah hadits Nabi SAW "bahwa beliau diperintahkan Allah SWT memerangi manusia kecuali telah mengikrarkan syahadat". Sebaliknya Abu Bakar r.a. berijtihad bahwa mereka harus diperangi dengan alasan telah memisahkan antara kewajiban shalat dan zakat.

Ada juga peristiwa lain yang melatarbelakangi ijtihad sahabat ini, yakni tentang kekhawatiran sahabat 'Umar r.a. terhadap keutuhan 
al-Qur'an yang dikarenakan gugurnya para penghafal (huffazh alQur'an) dalam peperangan, sementara al-Qur'an pada saat itu belum terkodifikasikan, sehingga menurut pendapat dari 'Umar r.a., alQur'an harus dikumpulkan dan ditulis dalam satu mushhaf. Namun pada awalnya Abu Bakar tidak setuju dengan pendapat 'Umar r.a., karena hal itu tidak pernah dilakukan oleh Nabi Muhammad SAW. Perbedaan pendapat itu berakhir dengan persetujuan Zaid bin Tsabit r.a. yang diberi tugas sebagai ketua panitia pengumpulan ayat-ayat alQur'an.

Dalam berijtihad, 'Umar ibn al-Khaththab seringkali, mempertimbangkan kemaslahatan umat, dibanding sekedar menerapkan nash secara zhahir, sementara tujuan hukum tidak tercapai. Seperti halnya, demi kemaslahatan rakyat yang ditaklukkan pasukan Islam di suatu daerah, 'Umar ibn al-Khaththab menetapkan bahwa tanah di daerah tersebut tidak diambil pasukan Islam, melainkan dibiarkan digarap oleh penduduk setempat, dengan syarat setiap panen harus diserahkan sekian persen kepada pemerintahan Islam. Sikap demikian diambilnya didasarkan atas pemikiran bahwa jika tanah pertanian di daerah tersebut diambil pemerintah Islam, maka rakyat di daerah itu tidak mempunyai mata pencaharian, yang akibatnya bisa memberatkan beban negara. Para ulama ushul fiqh berpendapat bahwa landasan pemikiran 'Umar ibn al-Khaththab dalam kasus ini adalah demi kemaslahatan (maslahah).

Sedangkan 'Ali ibn Abi Thalib juga melakukan ijtihad dengan menggunakan qiyas. Qiyas adalah dalil yang dikuatkan oleh naluri yang sehat dan ucapan yang benar. Adapun perbuatan sahabat dan ucapannya, adalah membuktikan bahwa qiyas adalah juga hujjah syar'iyah. Mereka benar-benar telah melakukan ijtihad terhadap kejadian-kejadian yang tidak ada nashnya. Mereka qiyaskan kejadian yang tidak ada nashnya. Mereka mengambil pelajaran pada sebuah bandingan dengan yang sebanding.

'Ali bin Abi Thalib meng-qiyaskan hukuman orang yang meminum khamr dengan hukuman orang yang melakukan qadzaf (menuduh orang lain berbuat zina). Alasan 'Ali ibn Abi Thalib adalah bahwa seseorang yang mabuk karena meminum khamr akan mengigau. Jika ia mengigau, maka ucapannya tidak bisa dikontrol dan akan menuduh orang lain berbuat zina. Oleh sebab itu, hukuman orang yang meminum khamr sama dengan hukuman menuduh orang lain berbuat zina. Adapun hukuman bagi pelaku qadzaf adalah 80 kali dera. Sehingga perkembangan permasalahan di zaman sahabat ini memerlukan upaya ijtihad yang semakin luas. 


\section{Analisis terhadap Ijtihad Sahabat}

Di dalam al-Qur'an dan Sunnah terdapat banyak hal yang mengundang pemikiran yaitu hal-hal yang belum sempat muncul pada masa hidup Rasulullah SAW. Munculnya pemikiran terhadap ketentuan hukum di dalam al-Qur'an ataupun Sunnah (sepeninggal Rasulullah SAW.), adalah disebabkan oleh berbagai faktor, terutama dari perkembangan masyarakat yang merupakan akibat makin meluasnya wilayah dakwah Islam, makin banyaknya bangsa-bangsa non-Arab yang memeluk Islam, dan juga makin banyaknya Sahabat Nabi yang menetap di daerah-daerah baru yang jauh dari daerah asalnya, serta munculnya madzhab-madzhab.

Selain bertebarnya para sahabat di berbagai daerah yang saling berbeda budaya, hal ini mempengaruhi para sahabat dalam menetapkan hukum. Akibatnya, dalam kasus yang sama, hukum di satu daerah dapat berbeda dengan di daerah lainnya. Perbedaan hukum ini berawal dari perbedaan cara pandang dalam menetapkan hukuman pada kasus tersebut. Selain itu, mengenai hasil ijtihad di kalangan sahabat memang banyak sekali permasalahan yang muncul akibat dari ketentuan hukum yang ditetapkan dengan jalan ijtihad tersebut. Dengan dipelopori sahabat-sahabat besar terutama al-Khulafa' arRasyidun dan para sahabat terkemuka lainnya seperti Zaid ibn Tsabit dan 'Abdullah ibn Mas'ud r.a. gairah ijtihadiah semakin berkembang, karena sudah mulai terasa keperluannya. Dengan demikian, pada masa sahabat, ijtihad sudah benar-benar berfungsi sebagai alat penggali hukum dan bahkan dipandang sebagai suatu kebutuhan yang harus dilakukan guna menyelesaikan berbagai kasus yang ketentuan hukumnya tidak secara tegas dan jelas mereka jumpai dalam al-Qur'an dan Sunnah.

Adapun perbedaan hasil ijtihad mereka itu terjadi antara lain karena perbedaan metode ijtihad yang mereka gunakan di samping latar belakang keilmuan dan orientasi penalaran yang berlainan. 'Umar ibn al-Khaththab, umpamanya lebih condong kepada maslahat di samping juga mempergunakan qiyas. Sedangkan 'Ali ibn Abi Thalib dan 'Abdullah ibn Mas'ud lebih banyak mempergunakan qiyas walaupun kadang-kadang sering juga memakai maslahat 'ammah.

Berdasarkan deskripsi di atas maka ada empat hal yang perlu penulis uraikan sebagai pandangan terhadap ijtihad sahabat. Pertama, fiqh pada masa ini terwujud dari suatu peristiwa ataupun kasus praktisi yang diikuti oleh kejadian-kejadian setelah itu terjadi, 
sebagaimana terjadi pada masa Rasululah. Mereka tidak terlalu mudah menciptakan hukum bagi kejadian-kejadian baru yang terjadi, sebagaimana yang dilakukan sebagian para Imam (madzhab) yang datang pada masa berikutnya, karena sempitnya peluang waktu mereka untuk melakukan pekerjaan ini dan karena dominasi ke wara'an (sikap yang hati-hati) pada diri mereka, dan sikap waspada yang tinggi untuk sampai terjerumus kepada kesalahan.

Kedua, para sahabat tidak mewariskan fiqh dalam bentuk yang sudah dibakukan, sampai berakhirnya masa ini, tidak ada suatu pun yang dibukukan dari karya-karya fiqh. Namun fatwa-fatwa yang mempunyai keistimewaan pada masa ini tetap terpelihara dalam hati para ulama, yang ditransformasikan lewat minoritas para sahabat dan mayoritas para tabi'in, kemudian mereka memberikan fatwa berdasarkan hukum-hukum tersebut pada kasus-kasus atau peristiwa yang memiliki relevansi, serta tidak ada usaha membukukan fatwafatwa tersebut.

Ketiga, kadar penggunaan mereka dalam ra'yu tidak sama, bahkan ada yang menghindarkan dirinya menggunakan ra'yu, atau malah khawatir kalau-kalau akan salah dan tergelincir dari agama Allah. Ada pula di antara mereka yang terlalu berani menggunakan ra'yu, karena memang sangat mampu.

Keempat, pada periode ini banyak terjadi ijtihad-ijthad yang mengubah sebagian hukum-hukum yang dulu pada masa Nabi SAW. dilakukan secara proporsional, khususnya pada masa Khalifah 'Umar ibn al-Khaththab r.a.

\section{Kesimpulan}

Dari uraian tersebut di atas maka dapat disimpulkan bahwa perkembangan pemikiran dalam bidang hukum Islam pada masa sahabat Rasulullah merupakan suatu tatacara untuk menetapkan hukum yang memerlukan suatu daya upaya yang sesuai dengan pemahamannya terhadap keberadaan hukum Islam yang harus ditegakkan dan dilaksanakan tanpa ada suatu tindakan maupun pandangan yang menyimpang atau menjauhi dari tujuan hukum Islam sendiri dan dasar-dasar hukum di dalamnya, yakni al-Qur'an dan Sunnah. Meskipun perbedaan selalu muncul di kalangan para sahabat, namun itu tidak membuat suatu pertentangan yang berarti pada permusuhan, tetapi ada hikmah di balik perbedaan tersebut, karena memang masing-masing sahabat pada waktu itu juga memiliki dasar serta orientasi keilmuan yang berbeda dan latar belakang pribadinya, 
yang tentunya semua itu mendukung sekali terhadap keputusan hukum yang dipergunakan untuk memecahkan masalah-masalah yang muncul dalam dinamika kehidupan masyarakat Islam di saat itu.

Tuhan menjadikan syariat yang dibawa Muhammad SAW.-lah syariat terakhir yang bisa berlaku untuk sepanjang masa, tetapi jumlah ayat al-Qur'an dan Sunnah terbatas, sedang kejadian-kejadian baru yang dihadapi manusia silih berganti sesuai dengan kemajuan yang terus berkembang. Sekiranya ijtihad dalam penetapan hukum tidak boleh, sedangkan nash-nash terbatas pada yang telah ada, maka akan menimbulkan kesempitan hidup, dan tentunya harus ada jalan keluar, dengan jalan ijtihad birra'yi sebagai yang dikatakan Mu'adz dalam hadits di awal tulisan ini.

\section{Daftar Pustaka}

Abu Zahrah, Muhammad. (1994). Ushul Fiqih. Penerjemah: Saefullah Ma'shum dkk. Jakarta: Pustaka Firdaus.

Ahmed, Al-Haj Moinuddin. (1992). The Urgency of Ijtiha., India: Kitab Bhavan.

Ali As-Saayis, Syekh Muhammad. (1995). Pertumbuhan dan Perkembangan Hukum Fiqh(Hasil Refleksi Ijtihad). Jakarta: PT RajaGrafindo Persada.

Djamil, Fathurrahman. (1999). Filsafat Hukum Islam. Jakarta: Logos Wacana Ilmu.

Hallaq, Wael B. (2001). Ensiklopedi Oxford Dunia Islam Modern. Bandung: Mizan, Bandung.

Haroen, Nasrun. (1997). Ushul Fiqh 1. Jakarta: Logos Wacana Ilmu.

Hasan, Ahmed. (1994). The Early Development of Islamic Jurisprudence. Delhi: Adam Publishers \& Distributors.

Khallaf, Abdul Wahhab. (1996). Kaidah-Kaidah Hukum Islam (Ilmu Ushulul Fiqh). Penerjemah: Noer Iskandar Al-Barsany \& Moh. Tolchah Mansoer. Jakarta: PT RajaGrafindo Persada. 
Mudzhar, M. Atho'. (1998). Membaca Gelombang Ijtihad: Antara Tradisi dan Liberasi. Mathori Al-Wustho (Editor). Yogyakarta: Titian Ilahi Press.

Qardhawi, Yusuf (dkk). (1987). Dasar Pemikiran Hukum Islam (Taqlid $x$ Ijtihad). Penerjemah: Husein Muhammad. Jakarta: Pustaka Firdaus.

Rahmat, Jaluddin (Editor Tamu). (1996). Ijtihad Dalam Sorotan. Bandung: Mizan.

Syarifuddin, Amir. (1997). Ushul Fiqh Jilid 1. Jakarta: Logos Wacana Ilmu.

Syihab, Umar. (1996). Hukum Islam dan Transformasi Pemikiran. Semarang: Dina Utama.

Yusdani, Amir Mu'allim. (1997). Ijtihad Suatu Kontroversi Antara Teori dan Fungsi. Yogyakarta: Titian Ilahi Press.

\section{Biodata Penulis}

Tri Ermayani, M.Ag, dilahirkan di Bantul, 3 Juli 1976. Pendidikan terakhir diperoleh dari Program Pasca Sarjana (S-2) UIN Sunan Kalijaga Yogyakarta tahun 2000-2003 dengan Konsentrasi Pemikiran Pendidikan Islam Prodi Pendidikan Islam. Sekarang menjadi dosen tetap Al-Islam dan Kemuhammadiyahan Universitas Muhammadiyah Purworejo, dosen Pendidikan Agama Islam Universitas Negeri Yogyakarta (UNY), dan Redaktur Buletin IQRO' Team Tadarus "AMM" Kotagede Yogyakarta. 